\title{
Intellectual factor in African diplomatic history: Sokoto and Borno sultanates, 1786-1817
}

\begin{abstract}
Most Western writers consider the history of Sub-Saharan Africa in the pre-colonial period as records of dark accounts, conflicts and wars, which had virtually nothing to contribute to societal development and refinement. However, a close historical scrutiny of some aspects of history of the ancient states and empires of the region unfolds entirely new historical evidence negating such unfounded, but widely spread views. The emergence and evolution of diplomacy and foreign policy of the ancient states of Ghana since the tenth century, followed by empires of Mali, Songhai in western Sudan, and Hausa states, as well as the Kanem Borno and the Sokoto Caliphate in the central Sudan reveals excellent, constructive, bilateral and beneficial inter-state relations within the sub-region, and beyond to North Africa, Middle East and Mediterranean Europe. The focus of this paper will be on the ability of two African states to resolve their inter-state differences through dialogue and recourse to intellectual and diplomatic expertise instead of violence, massacre and butchery. These two states were the Sultanates of Borno and Sokoto, which emerged in the 14th and 19th centuries respectively, and jointly survived till the British occupation in the early 20th century. The use of dialogue and application of intellectual debate in addressing differences between the two states is a legendary historical antecedent worthy of note and emulation by the so-called civilized countries of today who use excessive military threat as a determining factor in their foreign relations. The unimaginable losses in human and material resources in contemporary period could have been so amicably averted following the example of these ancient African cum Islamic alternatives. These and many other lessons that could be derived from the African Islamic diplomatic history will be addressed in this paper.
\end{abstract}

Keywords: Borno-Sokoto sultanates, intellectual factor in diplomatic relations, peaceful resolution of inter-State conflict, Nigeria, Africa
Volume 2 Issue 3 - 2018

\author{
Mukhtar Umar Bunza \\ Department of History, Usmanu Danfodiyo University, Nigeria
}

Correspondence: Mukhtar Umar Bunza, Department of History, Usmanu Danfodiyo University, Sokoto, Nigeria, Email mbunza@hotmail.com

Received: April 10,2018| Published: June II, 2018

\section{Background}

\section{Islam in state affairs: Borno and Sokoto}

Historically, the Kanuri of Borno, according to Cohen \& Brenner, have one of the earliest and eldest known political histories not only in West Africa but in the African continent at large. That long political history was welded with scholarship and religion. Most of the Mais, (Mai- single- traditional title for Borno Sultans) of Borno were known as pious Muslims who had regards for knowledge and scholars. Islam remained as the state religion in Borno since the reign of Mai Hummay Ibn Abduljalil (1096 AD) in the eleventh century. Imam $\mathrm{Ahmad}^{2}$ Ibn Fartuwa, the chief historiographer of Borno Sultanate, presents Mai Idris Alauma as the Amir al-Mumineen (title for the leader of an Islamic state) and Vicegerent of Allah on earth, in the sixteenth century; the same title, which Mai Ahmad ibn Aliyu claimed for himself as the ruler of Borno. Ibn Fartuwa says:

We have undertaken to write of the Kanem wars which were waged by our Sultan, the Commander of faithful, the vicegerent of the Lord of the worlds in the land of Borno al-Hajj Idris, ${ }^{3}$ Ibn Ali (he inherited the duty of the prophets), he did not cease striving in jihad with tongue and lance and sword, giving good tidings and warning, a missionary in the path of peace, until truth appeared, emerging from error just as comes out from the darkness of night. This information indicates that Borno was not only an Islamic state in the 16th century, but also the defender of Islamic faith and promoter of the light of Islam that illuminates the Sudanese societies. In confirmation to this, Muhammad Nur Alkali, ${ }^{4}$ citing Muhammad bin al-Hajj bin Ali, outlines the religious foundation of Borno. The Mais had it as their guiding principle that the messenger of Allah (SAW) imposed on them the obligation:

-to worship God only, Him alone, who has no associate, and to obey Him and not attempt to defy Him- to rule with justice as God and His messenger gave judgment by the Book and Sunnah-not to oppress any of the servants of God, as God averts oppression from the two worlds-not to betray God or His messenger or the faithful-not to cheat except in war, for war is deceit -to support the religion and the jihad in the way of God, but not from caprice -to hold fast to the rope of God together and not be afraid or disunited-to call people to God by means of wisdom and good advice-to do our utmost to be righteous both inwardly and outwardly.

This code of reference in the administration of Kanem Borno suffices a reason for it to have a stake to engage any other state or individual that questions it religious integrity or at least disregards its sanctity as an Islamic state. This position served as a turning point for the Kingdom of Borno above any other state in the Central Sudan in addition to its political and religious credence in the Muslim World at the time. In the field of scholarship, Borno had no equal in the pre-nineteenth century central Sudan. Apart from its economic and political dominance, 'its intelligentsia, according to YB Usman, ${ }^{5}$ had developed a powerful tradition of Islamic learning and active participation in public affairs long before the coming of Islam in Hausaland'. It was due to its thorough observance of the rule and tenets of the Shari'ah that Dunama's son Biri I,(a prince of Borno) was put in prison by his own mother for executing some thieves instead of amputation as required by the law. Borno also had established a strong connection with North Africa and Egypt since the 14th century for the 
training of its students for advanced studies especially in al-Azhar University. Due to its high position in the sphere of knowledge and memorization of the holy Qur'an, Sultan Muhammad Bello ${ }^{6}$ 17811837, mentions in his book Infaq al-Maisur:

Before this holy war took place no country in our land surpassed (Borno) in prosperity... Wadai and Bagarmi were formally subject to the Sultans of Borno, as also Hausa and the neighboring parts of Bauchi. Later, their power declined. Many of their chiefs made pilgrimage and they were prosperous and contented in the Muslim faith. They stood fast by the law and custom of Islam. Islam was widespread throughout their land. It is known that their chiefs and Wazirs and the rest of their people were Muslims... There are no found in our towns, students and writers of the Qur'an equal to theirs. It is stated that they remained steadfast up to the time that our jihad began.

This statement from Sultan Muhammad Bello ${ }^{6}$ in favor of Borno was a testimony to its greatness, politically and religiously in the central Sudan. Its fame and dominance in the political and economic structure of the Sudan confirmed its influence over the most prosperous and strongest Hausa states like Kano, Katsina and Daura. The military assistance therefore, Borno offered to these states during the 19th century Jihad, which became the main cause of conflict with the Sokoto Sultanate could be understood in the light of a stronger state protecting its vassals against invasion; more so that they were paying annual tribute to Borno before the outbreak of the jihad.

At the beginning of 19th century when the activities and campaigns of the Sokoto Jihadists were intensifying at Degel in the Gobir Kingdom, Borno was the strongest state in the central Sudan that had the capacity to effectively resist their mugging. Within a short period of time the waves of the reform initiated by Shehu Danfodiyo ${ }^{7}$ had shaken the entire Hausa societal structures to its foundation. The reform movement aimed at redirecting and tailoring the society based on the return to pristine Islam and emphasis on the observance of the Shari'ah in the state affairs.

The Shehu and his followers were already in conflict with the ulama'a, (scholars), rulers and other protectors of the traditional institutions who felt threatened with the activities new emerging political entity under Sokoto leadership. Further to the conformity in the practice of the religion, the jihadists were more concerned with the issues of social justice, freedom from oppression and general administrative malpractice that were prevalent in the then Hausa societies. These offences, were mostly perpetrated by the rulers with the support and approval of the venal ulama', scholars, who Shehu Danfodiyo $^{7}$ condemned as collaborators in undermining the religion and also rebuffing the rights of the masses in return for influence and/ or material gain.

Shehu Usmanu Danfodiyo, ${ }^{8}$ 1754-1817, the leader of the Sokoto Sultanate, directed all the forces and resources for the reform, which had more emphasis on preaching and teaching rather than military campaigns. The scholarly disposition of the leaders of the movement, according to Murray Last, impacted on the nature and character of their reform movement and the new state of Sokoto they established. Consequently, the jihad movement thus, became distinct from the other similar movements in West Africa in the nineteenth century. That was why the Sokoto leadership could engage al-Kanemi of Borno Sultanate, in dialogue and intellectual exercise instead settling the case in battle field.
By 1809 almost all Hausa States were conquered by the Sokoto Jihadists; and a capital seat of the newly established caliphate was founded at Sokoto. This emerging Islamic state naturally posed a new intellectual, religious and political challenge to the dominant state of Borno in the region. The political and religious influence of Borno in Northern Nigeria had provided it with a new role of acting on behalf of other states of the area, especially those that sought for its protection against the new power, the Sokoto Sultanate in the 19th century. Abdullahi Fodiyo, ${ }^{9}$ 1766-1827, Prime Minister of the Sokoto Sultanate, 1809-1820, reported in Tazyin al-Waraqat, that as early as 1786 Mustafa Gwoni from Borno, queried some of their activities He wrote a letter admonition the Shehu on the conduct of preaching and teaching with women in attendance with men. The letter reads in stanzas as follows:

To you, from us, blessed greetings which caused those who meet us to smell musk and perfume. O son of Fudi, rise and warn the ignorant, that perchance they may understand religion and things of this world. Forbid women to visit your preaching, for mixing of men and women is sufficient a disgrace. Do not do what contributes towards disgrace, for God has not ordered vice which would cause us harm. The verses of al-Mustafa thirteen complete them, in the year twelve hundred, plus a number which will suffice us.

As far as was available to this research, no scholar had made such a scholarly approach to what the Shehu and his companions were doing before this Bornoan scholar. This also further confirms the level of concern the Bornoans had in the religious development of the region. In order to respond to this challenge Shehu instructed Abdullahi to answer him. Abdullahi in demonstration of his eloquence and intellectual ability followed the same pattern of the poem and answered in the following:

O you who have come to guide us aright, we have heard what you have said. Listen to what we say. You gave advice to the best of your ability, but would you have freed us from blame! And you spoke- Glory be to God, this was calumny! Indeed devils, if they come to our gathering, spread evil speech, exceeding all bounds! We have not had promiscuous intercourse with Women, how could that be... But I do not agree that their being left to go free in ignorance is good, for the committing of the lesser evil has been made obligatory. Ignorance pardons, even though it was disobedience. We found the people of this country drowning in ignorance; shall we prevent them from understanding? Their number is ten. And the date is twelve hundred and one (i.e.1201 A H approximately $1786 \mathrm{AD}$ ). No further detail was given about this scholar from Borno - Mustafa Gwoni- and what were his reactions after this response by Abdullahi Fodiyo in this account. Unlike the Yandoto scholars in Zamfara Kingdom, who were renowned for their knowledge and reputation, but could not make any formal presentation of their case against the jihad movement in writing, the Borno scholars proved to be more erudite and studious. The failure to confront the Shehu and his followers academically by the Yandoto scholars as against the confidence of the Bornoan scholars astonished Bello in his account:

After that we made an expedition against Yandoto. Now there were Mallams remaining in Yandoto. For in ancient times it had been a city renowned for its mallams. Some of these Mallams were saying that we were in error and were misleading the people of the Soudan... Then I sent my comrade Muhammadu, son of Ashafa with a message to them. I told him to inform them I had not come to make war upon 
them but had come and camped close to them in order to talk to them. If it shall be prove that we were in the right then they should repent and follow us, but if they were in the right then we would repent and leave that which we were set. When my messenger told them this, they said to him, "we will not talk to him at all; we do not even want to see him, lest God not join us with him and his father in this world and the next. Dialogue which became a living legacy of the Borno scholars in their encounter with Sokoto Caliphate was such a healthy development which Muhammad Bello advanced to all other disputing states such as Zamfara through the Yandoto scholars of the Kingdom. Under this premise therefore, the challenge posed by Shaikh al-Amin al-Kanemi could be seen as continuation of a legacy, exemplary of Bornoan scholarship, and diplomatic maturity. The historical significance of the diplomatic disputations and debates between Shaikh al-Amin alKanemi (the famous Kanembu scholar who featured in the politics of Borno in the 19th century), and the Sokoto Jihad leaders is indubitable in understanding of nature of traditional foreign policies in Africa. From the beginning of Jihad activities in the late 18th century, the Borno scholars expressed a keen interest in the new political and religious climate that was evolving at the time in the central Sudan.

On the other hand, the responses of the Sokoto leadership to these challenges were important fountain for intellectual and administrative legacies, as well as exemplary inter-state and diplomatic bequest worthy of emulation in African continent and beyond. Some of the most remarkable points were the fact that the disputations and debates were based on reason, with sound academic and intellectual posture as well as with high sense of personal respect and civility. It is interesting to find that, for intellectual objectivity, the Prime Minister of the Sokoto Sultanate supported the position of Borno Sultanate against the position of his own state because of superior proofs and evidences. In consideration of the enormous historical lessons in the disputes, the paper examines its significance in the contemporary period especially in relation between nations.

One of the basic factors for the intellectual discourses that took place in the 19th century between Borno and Sokoto Sultanates were the capability and position of each of them to defend whatever action it had taken intellectually and authoritatively, not by use arms. It is also worthy of note that the religion of Islam was very central to the two disputing states especially in the administrative and diplomatic affairs. Thus, it was normal for them to have debated on anything which was seen as contravening the basis and tenets of the religion on which their states structures were founded.

\section{The stake of the scholars in inter-state disputes: The} al-Kanemi in Borno-Sokoto Diplomatic tussle

The reason behind the apprehension, and the prompt reaction of Shaikh Muhammad al-Amin al-Kanemi (on behalf of the Borno Sultanate) to the affairs of the Sokoto Caliphate continued to remain a source of controversy among writers. Scholars like Kyari Tijjani see it as means of discharging his responsibility as a Muslim scholar whose role and function in the state must go beyond his personal need and aspirations, but to defend the interest of the masses, at national and transnational dimensions. On the other hand, scholars like Brenner and Cohen view al-Kanemi's challenge to Sokoto as part of making political calculation that would favor him at the end of the game. Cohen and Brenner opine that:

Al-Kanemi's communications with the leaders of Sokoto served to enhance his prestige in Borno. There is no evidence to indicate that he wrote these letters at the request of or as the agent for the Mai. It seem as though he initiated the correspondence independently because of his interest in the matter as an educated, and probably ambitious man who undoubtedly believed that his judgment about this controversy were, or should be of importance to these leaders directly involved.

The views of Brenner and Cohen show that al-Kanemi's involvement into the diplomatic dispute was in expectation of political gains, so as to change his status from an ordinary scholar to a political arbiter and a potential administrator. The same way YT Gella ${ }^{10}$ also perceived the al-Kanemi's participation as a mere infringement in the affairs he had no stake. In his opinion:

The issue at stake in the debate that raged on between al-Kanemi and the Jihad leaders had little to do with Islam as a religion, though this was made the central issue in the correspondences. Rather it was an issue of power relationship, that of subordinate and super-ordinate relationship... It is clear that Shehu Usman ${ }^{7}$ \& Muhammad Bello ${ }^{11}$ regarded the Borno alim as a foreign intruder who had no business defending the rulers of Borno.

Gella $^{10}$ did not provide any place in the writing of the Sokoto leaders where they made such comments against al-Kanemi in the course of their dialogue or even after. However, in the accounts of Muhammad Bello in Infaq al-Maisur, and Abdullahi ${ }^{12}$ in Tazyin alWaraqat on this matter, they recognized him as a competent, sincere and God fearing scholar with every right to defend and speak on behalf of his government. They really considered him as a person with full stake in the matter and never even at once questioned his legitimacy and credentials for the intervention between them and the Borno Sultanate. Further, the role and position of the ulama' scholars-in the central Sudan in 19th century were not placed in the proper perspective by Gella in making such assertion. The ulama' performed various duties such as religious and political propaganda, they adjudicate, settle disputes, preside over ritual activities, advice the kings, serve as court clerks, and above all were regarded as saintly people of God. The authority surrounding the personality of a scholar was great, such that a successful ruler had to be a close associate of ulama'-scholars-for advice, guidance and prayers. This was seen in the case of al-Kanemi at Ngala, or Shehu Danfodiyo during the reign of Bawa Jangwarzo in Gobir Kingdom. The arbitration role of the scholars on private or public matters was not in doubt. After all, the cause of the debate between Sokoto and Borno Sultanates was more juristic and scholarly in nature such that ulama' scholars were the most expected to thrash on the matter for the proper guidance and resolution of the crisis.

\section{Issues in diplomatic and bilateral debate: Sokoto against Borno}

The main points of contention between the most strongest 19th century West African States, ${ }^{13}$ (Sokoto and Borno) were:

1. Whether aiding the Hausa states against the forces of the Sokoto Sultanate by Borno constituted unbelief or not.

2. If so, would that be a sufficient reason for the Sokoto Sulatanate to declare Jihad against Borno?

3. Whether such practices as corruption and syncretism etc. can lead to unbelief and render a country guilty for attack by another?

The primary materials used in this discussion were correspondences compiled by Sultan Muhammad Bello in his book Infaqul Maisur, and 
some other relevant accounts on the matter. Although, both Brenner al-Kanemi ${ }^{14}$ and Bello lost some of their letters on the transit, however, nine of these correspondences were preserved by Bello; five from the Sokoto Sultanate, while the remaining four from Borno Sultanate via al-Kanemi.

The point that should be clearly understood here is the question of who was a Muslim in Hausaland and Borno at the period. A Muslim in the definition of the Shehu was the one who accepted and practiced the tenets of the religion of Islam and identify himself with the people of the same ideology. Mixing of Islam with traditional religious practices such as offering sacrifices to objects like trees, mountains, streams, collaborating with or assisting the non-Muslims to fight a Muslims in the definition of the Shehu were some of the acts that constitute unbelief. Shehu presents the categories of Muslims in Hausaland in the 19th century as presented in his book, Nur al-Bab. In Sokoto perception; whoever mixes Islam with traditional religious practices, or performs any of the above actions seizes to be a Muslim regardless of his prayers, fasting, and other religious obligations. According to MA al-Hajj, ${ }^{15}$ that resulted to sharp polarization of the Muslims in the entire Central Sudan based on ideological lines across countries:

This legal argument was of course intended as a tactical operation to mobilize the revolutionary forces in Hausaland. It was easy for the Jama'a (the followers of the Shehu) in any part (country) of the region to brand their ruler as unbeliever and either rise against him or immigrate to territories already conquered by the Shehu and his companions. This explains the curious way in which uprisings took place (including that of Deya in Borno and in) in different parts of Hausaland almost simultaneously. ${ }^{16}$

Dar-al-Islam (abode of Islam) and Dar al-Harb (abode of unbelief) were clearly identified. In his magnum opus -Kitab Bayan wujub alHijrah ala al-Ibad, the Shehu says: 'there is no disagreement (among classical Muslim authorities) that the status of land is judged in accordance with that of its ruler-if the ruler is a Muslim the land is of Islam, and if he is an unbeliever, the land is the land of unbelief... there is no disagreement in regard to the obligation incumbent upon Muslims to depose their ruler, who is an unbeliever, ${ }^{17}$ if they raise against him and overcome him. If they cannot do so they are not required to rise against him, but every one of them is under the obligation to emigrate from the land of such a ruler to somewhere else'. Upon this premise one can easily understand the basic foundation upon which the rule of the Borno leadership was rejected by the followers of Shehu residing in the domains of the Bornoan leaders in the 19th century. Bello explains the situation as its affected Borno and its relations with the Shehu's supporters in the following:

At the time when our people in those countries (Borno) were pressing against the Sarkin Daura and Sarkin Katsina and Sarkin Kano all these chiefs sent to Sarkin Borno and sought aid from him against our Moslems. Then Sarkin Borno sent his Wazir (Galadima) and did what is known. The chiefs were aiding their brother chiefs against our enemy who was conquering them. Then $\mathrm{W}$ aziri (Galadima) directed his forces as he had been commanded. ${ }^{18} \mathrm{He}$ sent a raiding force to the people of Daura, and made preparations in order to come to the aid of Sakin Daura and Sarkin Kano and Sarkin Katsina even as Sarkin Borno had commanded him. When their neighbors, our folk, who were there heard news of his coming they assembled together in one force. Then Waziri came forth himself and raided our people and drew up his force in battle against them... our folk in Borno who were in alliance with Shehu did not wait for Sarkin Bornu to attack them but started to go and join Buba Yero in Bauchi, and assist him in the jihad, others of them went to Abdua and assisted him in the jihad. Now when they heard that Sarkin Borno was making preparations and intended to assist the Hausa chiefs they were afraid in their hearts and rose up in flight. All those in the south (of Borno) went to Buba Yero and all those in the west to Abdua. ${ }^{19}$

The alliances of the Borno Sultanate with some Hausa Kingdoms were the major factors that brought Sokoto Sultanate into conflict at first with the state of Borno. Probably it was Mai Ahmad through his envoy Alhaji Adamu who started the diplomatic consultation so as to find out the reasons for the conflicts and ways of resolving the crisis, as well as giving assurances to Sokoto citizens and followers residing in Borno of their security and safety, thus needed not to flee. Mai Ahmad ${ }^{20}$ (around 1804-1810) therefore, started the dialogue with Sokoto before al-Kanemi took over the whole stage. He (Mai Ahmad) directed Adamu, his vizier, to further inform Shehu that the Sarkin Borno was the Sarkin Musulmi i.e. a Muslim ruler of an (independent) Islamic state.'

Consequent upon receiving the message from the Sultan of Borno, the Shehu directed his son Muhammad Bello to respond to the letter which Bello explained the content that:

I explained to him (Sultan of Borno) the causes from which the holy war had arisen and explained them very fully. I described to him the general character of the Hausa chiefs. I said they were heathen and I further said that all who aided those chiefs were like them. I warned him to be ware lest they deceive him and drew him into their affairs. Finally, I sought his assistance for the Muslims against these heathen. This response informs us that as far as the Sultan of Borno was concerned, the Sultanate leaders had no problem with him at the initial stage. That he was considered as somebody not quite aware with the problem on ground as regards the position and status of the Hausa rulers. Finally in order to accomplish a peaceful accord with him, Bello wrote to the Muslims to keep peace and respect the Borno authorities, and not to emigrate from the country again. ${ }^{21}$ According to Louis Brenner, it was the total disregard of Bello's letter by Mai Ahmad and his continued operation against the people of Shehu that severed the diplomatic relationship that seemed cordial at the beginning of the dialogue, which negatively affected the relationship between the two states in following decade. It was after that peace accord failed, that Sarkin Borno did not only respect the correspondence from Shehu but had passed forces against Wachakol (near N'garu), and his assault against Ardo Lerlima and also maltreated the Sokoto envoy. ${ }^{22}$ That what brought the Sarkin Borno now under the same legal position as the Hausa rulers as being lawful to be revolted against by the believers and overthrowing him obligatory by assent of the law? Consequently, the supporters of the Sokoto Caliphate in Borno territories: Buba Yero et al., ${ }^{23-25}$ and their followers led an uprising against the government following the position of the Sokoto Sultanate, which resulted to the takeover of the Borno capital Ngazargamu by the forces loyal to Sokoto. That was the circumstances that brought al-Kanemi into the fore front in the inter-state dispute between Sokoto and Borno. According to Kyari Tijjani, al-Amin al-Kanemi was a personality reputed for his sincerity, honesty; fear of God, and depth of knowledge the sterling qualities that made him a potential figure for leadership in the Muslim community. ${ }^{26} \mathrm{He}$ further states that: More significantly, he (al-Kanemi) seemed to have opened correspondences with the Fulani leaders in Deya, hoping to resolve the theological disputes by 
discussions as among scholars, a bid which seemed to have brought him fully to the notice of the political authorities in Borno. He thus, commenced his assignment by first writing to the Shehu as follows:

From al-Hajj Aminu son of Muhammad, El-Kanemi, ${ }^{27}$ to the Mallams (scholars) and principal men (leaders of the Sokoto Sultanate) of the Fulani, greetings and friendship: After greetings the reasons why I am sending this letter to you is that when the will of God brought me to the land of Borno I found the fire of discord had broken out between you and the people of this land. I enquire the cause of this. Some persons informed me that oppression was the cause, others again that it was religion. We were therefore perplexed by this matter and I wrote a letter to your brethren who are my neighbors. I besought them to explain to me their reason and pretext for making war on Borno. They sent me in reply a poor sort of answer, such as would not come from a wise man, much less from a learned one and least of all from one who is reforming people. They wrote me a list of titles of books and said that in these books they saw the reason of the war. Now we have examined these books and we do not see in them what they have seen. Thus we remain in our perplexity... In truth we have heard news of the character of Shehu son of Usman son of Fodiyo and we have read his books. Your actions are at discord with what is in his books. If it is a fact that what you are set upon is a project of Shehu's mind, well, formally we believed Shehu's character was noble, but if that is so, then his character is not noble. I wish to inform you, we are on Shehu's side if for the truth. If he is departing from truth, then we leave him and follow the truth.

It seems like al-Kanemi was aware of the charges against Borno, as he promptly says: 'If you tell me you have done this because of our heathenism, let me inform you that we are not heathens and heathenism is far from our thresholds'... You are told that our Chiefs go up to certain places and slaughter animals for the purpose of giving meat in alms; further you are told that their women do not veil themselves: further that their Alkalai (judges) take bribes, and waste the property of orphans and are oppressive in their judgments. But these five things do not make it lawful for you to make war upon them'... One of the most of important aspects of diplomatic achievement in this part of the world that at a point of crisis the parties involved had the patience of searching for reasons and justifications in books and weighing the strength of evidence put forward by the opponents. That was contained in the statement of Alkanemi's complain to the Sokoto Sultanate saying: "They wrote me a list of titles of books and said that in these books they saw the reason of the war. Now we have examined these books and we do not see in them what they have seen". Beyond any doubt, this is evidence that inter-state relations especially between these two Sultanate in the 19th century was basically on reason and intellectual discourse, war and military confrontation of any sort was the last resort and least alternative in deciding and settling of conflicts. Reasons are sought before going to war, unlike the practice of the superpowers today of going to war after which justification for it could be sought. This is an important contribution by this Muslim African region in world history that the modern world should emulate. When al-Kanemi's letter reached Sokoto, Abdullahi and Muhammad Bello replied it. However, only Bello's reply could be found in Infaqul Maisur. Muhammad Bello's reply goes:

From Muhammad Bello son of Sarkin Musulmi Shehu to Alhaji Aminu al-Kanemi greetings. After greetings, your letter reached us on 6th day of Sha'aban. You ask us reason why our folk are fighting with the people of the towns of Borno... It is evident that you have had information from one who had no information to give... we also wonder, al-Kanemi, how you can say we charge Muslims with heathenism on account of these five things. Where as in truth we let everyone whose Islam is proved. The reply was very lengthy enumerating the entire story of Shehus encounter with the Gobir rulers up to time of the outbreak of the Jihad. Then Bello also highlighted on the correspondence earlier received by Shehu from the Mai of Borno Ahmad son of Aliyu and how the peace proposal was severed and betrayed by the Mai himself. Finally, he dismissed the basis of information of al-Kanemi as unreliable, the same as his position to cast doubt on the character of Shehu. As if this reply was not enough Muhammad Bello followed his letter with another, in this regard he did not go into history; he straight away addressed the main issue, saying:

From Muhammad Bello son of Sarkin Musulmi Usman to Alhaji Aminu al-Kanemi. I received your message in which you ask the reason why we are fighting with your people and the reason why we are enslaving your people's children. This is to inform you that the reason of our fighting them is that they are helping the heathen Hausa against us. In truth you know that every man who helps the heathen becomes like them. Secondly, because you persist in worrying our folks who are your neighbors and even compel them to flight. It was you who began to fight with them just as the Hausa chiefs did to us. You are helping the Hausa against us. Well, we know the reason of your doing so. It is because you agree with that which they are set upon. You therefore are become like them. Your prayers and your giving of tithes, your fasting and your building of mosques shall not prevent our fighting you, and shall not benefit you in this world or the next, for you are helping the heathen against us. In the above correspondence one can observe some signs of anxiety on the part of Muhammad Bello as regards to their reasons as well as the legal and juridical proofs for fighting against Borno. In all the correspondences, what was popularized was not the case of unbelief against Borno on its own as an entity, but for Borno's assistance to Hausa rulers whose case of unbelief was beyond doubt by the new state of Sokoto. In this passage of the letter quoted above, which is about one-third of the content of the letter, one observes repetition and reverberation of a single reason as if the writer was not comfortable with himself; perhaps due to the contentious nature of the problem. Bello mentions that,...'they are helping the heathen Hausa..' he repeats again... 'every man who helps the heathen becomes like them'..., he says again... 'you are helping Hausa against us'..., he further reiterates... 'well we know the reason of your doing so. It is because you agree with that which they are set upon'..., he adds that...' you are therefore become like them...' and confirms thus... 'for you are helping the heathen...'. In each of these points, it sounds like he was responding to a high legal query above that of Shaikh al-Kanemi. As if to say it was not enough a reason to condemn them (Borno) as unbelievers or fight them because of what had been given as reasons so far. What immediately followed after the letter may suggest Bello's uneasiness over the matter. He quickly consented for peace and instructed Gidado bin Lema (the Wazir i.e. Prime Minister-of Sokoto Sultanate), to immediately write and convey the letter himself and to start negotiating for peace with Borno. Bello further presents that:

Now I continued to write letters each year and was seeking to make peace with the people of Kanem, my letters were lost in transit except one which reached them. We were at home when a letter came to me from Aminu al-Kanemi and in part this letter was friendly one. It was written in reply to a letter which Gidado wrote to him asking him to 
make peace between us... The Sokoto leadership thus encouraged alKanemi to seek repentance of his chiefs instead of making defense in their case, although they had no clear information about the position of these chiefs, Bello admits, however, from what they gathered from their sources and clear assistance that came from Borno to Hausa rulers were the basis of their action. But ultimately peace would be better than hostilities between them.

Finally, Shehu Danfodiyo himself wrote two more letters directly to al-Kanemi in the following: From the Sarkin Musulmi, the leader of the Muslims Usmanu son of Fodiyo to Mallam Aminu, al-Kanemi, a thousand greetings and friendship... we wish you to know our way of life. Our way of life is that of the people of faith. It is our folk who have found the truth and we follow it. We also request you to command the Sarkin Borno and his people to repent and turn to God, and leave all those customs which are contrary to the law, so that they may become like their neighbors our folk, and cease from fighting with me... but if they choose what is not in accord with the faith and return to their same disposition as of old, then it is not lawful for you, Kanemi, to live among them, nor help them.

This message was even more appealing than the previous ones. Here Shehu (the President General of the Sultanate) was not only trying to foster peace but trying to win the support of al-Kanemi to join his camp, if the Borno leaders refused to accept his mission. The message also shows the position of repute and piety as well as the high intellectual esteem accorded to the person of al-Kanemi by the Shehu himself.

In response to these messages al-Kanemi wrote to Shehu the following reply:

From Alhaji Aminu, al-Kanemi, to the Mallam of great learning, Shehu son of Fodiyo, much friendship and may the grace of God and the blessings of God be multiplied to you... you know that our neighbors, your folk are ignorant people. Their ambition is to rule these countries and make conquest in every direction. We will not permit it... as regards your statement that you and your people are in the way of truth, this is correct and there is no one who would deny it. But our neighbors of your folk are not so. Had they indeed been as you are, then we would not have fought them... but let me inform you that any traveler or pilgrim may come and fear nothing from me. I will show no enmity to any Fulani (your follower) except he who comes against me in war. If indeed the people of Borno refuse my command in what is lawfully, if they harass the traveler, or trader, or pilgrim, then I remove my hand from their affairs and return to my place whence I came, and leave alone both them and their neighbors...

In the Shehu's reply to this letter, it further confirmed to al-Kanemi that he was innocent of any blame. The people he represented were charged based on their support to Hausa rulers, and the only way to peace, like what was sent to him earlier, were either repentance or payment of tribute. As for the person of Sheikh al-Amin, Shehu further clarified that: 'but do not you suppose al-Kanemi, that we accuse you of heathenism or your people because you aid the people of Borno against us. For how should we accuse of heathenism a Mallam -learned in law. Further, you say that you do not know the people of Borno to be heathens. In fact you believe them Muslims. Those also their neighbors, our folk, are Muslims. That is your belief'. Throughout the dialogue, Brenner pointed out that, both parties involved (envoys of Sokoto and Borno) agreed that there were wrong doings in Borno societies, however, what he (al-Kanemi, the Borno envoy) refused to agree (was) that these offences did not constitute disbelief. Such acts were sinful and the perpetrators should be punished, but argued alKanemi, 'they do not render a person an unbeliever so long as his faith remains unbroken even in sin'. The Shehu and Bello (from the Sokoto side) also agreed on this point but differed on assisting the Hausa kings in their fight against the Sokoto Caliphate. Not surprisingly, the position of the second in command in the Sokoto Caliphate and full brother to the Shehu, Abdullahi bin Muhammad bi Fodiyo differed sharply with his companions on the fundamental basis of the dispute.

\section{Non-partisanship and support for reason and superior evidence in traditional muslim African diplomacy: Abdullahi bin fodiyo in support of Borno against Sokoto}

The intellectual nature and scholarly orientation of the 19th century Hausaland provided avenue for freedom of opinion and independent judgment among the pioneers of the reform that brought about the emergence of the Sokoto Caliphate. This was visibly manifested in the stand of Abdullahi Fodiyo who was the Prime Minister of the Sokoto Caliphate, and younger brother, and unalloyed supporter of Shehu Usmanu Danfodiyo,(the President General of Sokoto Caliphate) on the subject of dialogue against his brother Shehu and his nephew Muhammad Bello. In the opinion of Abdullahi, assisting the Hausa kings in their fight with Sokoto cannot constitute unbelief under Islamic law. The position he continued to clearly and fearlessly argue out in his books, especially his tafsir-exegesis of the glorious Qur'an-Diya'a al-Ta'wil fi ma'ani al-Tanzil, and others of his books such as Diya' al-Hukkam refuting the evidences put forward by the Ameer Mu'mineen Shehu Danfodiyo and Sultan Muhammad Bello. Further, the nature, character and commitment to truth in the person of Abdullahi were made bare by that opinion he held. About Abdullahi's unwavering posture regarding the truth, Gwandu shows that 'he (Abdullahi) was guided not by personality but by ideas'. What brought Abdullahi in disagreement with his kinsmen, and government he strove to establish was the strength of evidences presented by them. In spite of the fact that Shehu tried hard to convince him as presented in his book Najm al-Ikhwan quoting the ruling of alMaghili on the case of Sonni Ali and Askia Muhammad of Songhay and other related sources, Abdullahi remained resolute that assisting non-Muslim against a Muslim cannot constitute unbelief, to warrant an assault on a sovereign state. Although, he accepts that helping the non-Muslims with the intention of denouncing the faith of Islam can constitute unbelief, but not helping the non-Muslims while one retains his faith. ${ }^{28-39}$ Abdullahi says in his tafsir, Diya' al-Ta'wil :

Generalization in anathematizing those who mingle the truth with batil (untruth) is clear if (that charge) is established. This is because the truth (here) means Islam and the batil means unbelief and clearly anyone who mixes Islam with kufr (unbelief) is surely unbeliever as clear stated. However, his anathematization of those who assisted the unbelievers in their armies against the Muslims armies is not clear to me because the verse which al-Maghili quoted (in support of his assertion) was revealed in respect of assistance given by the Muslims to unbelievers in furtherance of their unbelief in line with the normal practice of the hypocrites, concerning whom the verse was revealed as the Mufassirun (exegetics) have explained. Thus assisting them in unbelief is unbelief. However, he who assists them in sin cannot be regarded as an unbeliever so long as he does not 
regard that (sinful action) as permissible and lawful. The sending of armies against Muslims (as accused Borno of doing) itself does not constitute unbelief but rather it is a sin, if it is based on tawil (genuine interpretation allowing that). What more of mere assisting in that? And if an action itself does not constitute unbelief, how then can what it leads to constitute unbelief? As for Ibn Abd al-Karim al-Maghili, he did not qualify the meaning of the word nasr (assistance). It should, therefore, be taken to mean assisting them in committing unbelief and not in committing something sinful. This will bring (the ruling) in line with the views of orthodox Muslims. May God protect him (alMaghili) from making the taking of arms against Muslims as act of unbelief. Were the shaykh (Usman) to delete his words 'in their armies against the armies of the Muslims' it would have been better since we know, by necessity, that a Muslim does not become an unbeliever by fighting a fellow Muslims, what more of his just giving assistance (to unbelievers) in their fight against Muslims? By the opinion of Abdullahi, the Sokoto had no case in their dispute with Borno, and rather supported the opposing state following clear evidence and facts, not any sentimentality. It was apparent that, he (Abdullahi) subscribed to the opinion of al-Kanemi on this contentious and litigious matter and allowed his kinsmen to go by their understanding.

\section{Conclusion}

History's main role is to teach lessons; to make people utilize their past for their present and future and learn from the actions of man. The dialogue that had taken place for the past two hundred years reveals a lot of legacies for the emulation of this generation and the generations yet unborn. It is fascinating to find that the level of civility exhibited in the process of the Sokoto-Borno diplomatic quagmire had surpassed most of what could be attained even among the so-called 'civilized' countries, let alone their relations with the weaker nations- the socalled third world. A great deal could be learnt and deduced from the dialogue in terms of inter-personal relationship, intergroup relation, international affairs and diplomacy and more so on religious tolerance and administration. One of the greatest achievements of this debate was the use of dialogue and inquiry about the actions of the people before passing judgment on them even if they were seen operating on the wrong track. When the Shehu's followers at Deya-Damaturu rebelled against the Borno Sultanate based on their conviction that it was legal for them to do so; a responsible scholar on his accord wrote to them seeking for justification of their action from them. Not even the world's most civilized countries like America, France, Germany or Russia can be patient enough to seek for legal and intellectual justification for an attack on her. As it is witnessed today a country can be attacked or annexed for mere rumor and unconfirmed evidences like the case of American invasion of Iraq in 2003. African legacy and glorious past thus, has a lot to teach the world.

Similarly, after realizing the intellectual deficiency of the Sokoto supporters through their unintelligent reply, still instead of exterminating them militarily, the query was further directed to their leaders for more scholarly and convincing reasons with which to avert the conflict and adopt the way of peace. Regards for scholarship and learning that was demonstrated by the two nations even at the height of tension between them was a great lesson for nations in the contemporary period. Al-Kanemi, in spite of the tension and the state of war that they were witnessing had the patient and courage to go through the list of books which the opponents claimed authorized them to wage war on them. Travellers, traders, and all innocent citizens of a nations in another territory must be protected at whatever situation between the disputing states,. That was demonstrated in theory and practice throughout the Sokoto-Borno dispute.

In the same way, flexibility and sacrifice could be learnt from the dialogue as a commendable service expected of a responsible leader in pursuit of peace for his people. Both parties showed a high level of flexibility from their correspondences and avoidance of rigidity and imposition of ones opinion over another. In spite of the fact that Shehu raised charges against the rulers of Borno in the process of the dialogue, a simple of evidence of repentance from al-Kanemi on behalf of his client was requested to resolve the matter. In the course of peace we also leant that al-Kanemi threatened in case the people he represented refused to consent for the peace and terms of agreement once reached, would no longer be with them, rather will follow the truth. In his statement thus:

'If indeed the people of Borno refuse my command in what is lawfully, if they harass the traveler, or trader, or pilgrim, then I remove my hand from their affairs and return to my place whence I came, and leave alone both them and their neighbors'.

Firmness and flexibility from both the sides of Shehu and alKanemi on the issues of law and its applicability and considerations of necessity and circumstances is another legacy that could be a source of guidance for the Nigeria, Africa, and other world nations especially in the current turmoil that characterized the modern world. In the management of pluralism and religious tolerance the dialogue serves as milestones for the contemporary world. Integration of the Fulani and other tribes and their treatment on equal basis with the all members of the Borno society was one of the lessons of the debate to the multi-ethnic Nigerian and African states, let alone European countries where certain peoples are attacked, killed or maimed due to their race or color.

Respect for leaders and scholars, is another relevance of the dialogue for our time. Shehu in his respect to al-Kanemi and regard for his scholarship and wealth of knowledge after acknowledgement he also confirmed the high regard and respect he owed to him. And that it was only in the course of justice he disagreed with him but remained honorable in their sight. If the Shehus' statement: 'how should we accuse of heathenism a Mallam learned in law (like you)', show diplomacy in practice at a time of tension and conflict. Peace and resolution of crisis should be the ultimate in all disputes and debates and parties concerned should yearn for it and work for its attainment. That was what at last the dialogue aimed to achieve, and had succeeded in doing so. Let not superiority in military or territorial potentialities deceive a nation as to make war as its only gift to other countries. Al-Kanemi proposed for peace immediately, Shehu regardless of any other thing says: ' now when you say let us make peace and that there is every advantage in making peace, that is a good proposal. It is right that we and you should make this peace. We indeed seek nothing but what is right. May God help us and you to make this peace'. The refined and civilized approach in settling dispute between these two Muslim African states still eludes the world we live in today. The dialogue further strongly shows that Muslims in particular and Africans in general had evolved means of conflict resolutions and crisis management before the coming of the European invaders who portrayed Africa before their 'Civilizing Mission' as war mongers and knew nothing like reconciliation and concord.

Further, the dialogue throws a unique guiding light in inter-state relations as in spite of conflicts between the two states the bilateral 
relations and diplomatic considerations did not collapse in spite of the war that broke out between them. They recognized and respected international laws. Travelers, visitors, traders and other legally sanctioned persons enjoyed asylum, protection and consideration of each state. Al-Kanemi says,' let me inform you (regardless of our dispute) that any traveler or pilgrim (from your country) may come and fear nothing from me'. That was incredible and wonderful development that the so called developed world could learn from Africa. On personal ground it is important to note that from the dialogue even at the point of disagreement person's dignity should be respected. The opening and closing clauses of the correspondences convey a lot of lessons on this. The actors involved in the dialogue even at the time of serious criticism, like when the character of Shehu was questioned by al-Kanemi there were signs of self-restrain and self-control from both parties as not to allow sentiment to prevail over reason and sound evidence. And finally, as a result of this they were able to understand and resort to peace. Another profound example from the encounter and dialogue was non partisanship and lack of acquiescence to sentiments. In the whole event Abdullahi (Vice President and Prime Minister of the Sokoto Sultanate) was watching and following the dialogue and arguments advanced from both sides. He finally sided with Borno and disagreed with the views of his superior and his own government for the sake of truth and objectivity. This impartiality exhibited by this highly placed political leader is worthy of emulation by diplomats who defend the positions of their states wrongly or correctly with unmeasurable egoistic sentimentalities under the guise of nationalism and patriotism.

\section{Acknowledgments}

None.

\section{Conflict of interest}

The author declares that there is no conflict of interest.

\section{References}

1. Cohen R, Brenner L. 'Bornu in the Nineteenth Century'. In: Ade Ajayi JFA, Crowder M, editors. History of West Africa. Great Britain: Longman; $1974.93 \mathrm{p}$.

2. Imam Ahmad Ibn Fartuwa. The Kanem Wars: from Sudanese Memoirs. London: Cass; 1967.15 p.

3. Al-Hajj MA. "The Meaning of the Sokoto Jihad". In: Usman, editor. Studies in the History of the Sokoto Caliphate. Nigeria: Ahmadu Bello University; $2015.17 \mathrm{p}$.

4. Alkali MN. Islam in the Central Bilad al Sudan and the emergence of the Kingdom of Borno. In: Alkali MN, editor. Islam in Africa: Proceeding of the Islam in Africa Conference. Nigeria: Spectrum; 1993. $171 \mathrm{p}$.

5. Usman YB. A Reflection of the History of Relations between Borno and Hausaland before 1804. In: Usman B, Alkali N, editors. Studies in the History of Pre-Colonial Borno. Zaria: NNPC; 1983. 236 p.

6. Muhammad Bello, Infaqul Maisur, Arnett. book Bello enlisted a number of Bornoan scholars of repute who contributed to the scholarly rejuvenation of Hausaland for centuries. 8-9 p.

7. Shehu Usman Bin Fodiyo, Kitab Nur al-Bab, 1

8. Usman. A Reflection of the History of Relations. The International History Review. 1988;10(2):282-302.
9. Abdullahi Fodiyo, Abdulhamid A. Contribution of the Sokoto Jihad leaders to Qur'anic Studies. In: Usman, editor. Nigeria: Studies in the History of the Sokoto Caliphate; 1999. 189-190 p.

10. Gella YT. The Foreign Policy of the Caliphate of Muhammadu Bello (1817-1837) towards the States of Borno, Adar, Ahir and the West. In: ABU, Zaria, editors. Newyork: Bello University; 1986. 414 p.

11. Muhammad. Seven different letters were compiled in this book; five of them were responses to the two letters received in Sokoto from alKanemi. London: Oxford university press; 102-120 p.

12. Abdullahi. The Vision and Mission of Shaikh Abdullahi Fodiyo. In: Boboyi H, Yakubu AM, editors. Nigeria: The Sokoto Caliphate: History and Legacies; 2006. 1804-2004 p.

13. Reform in West Africa: the Jihad of the nineteenth century. In: Ade Ajayi JFA, Crowder M, editors. History of West Africa. Great Britain: Longman; 1974. 1-29 p.

14. Brenner L. The Shehu's of Kukawa: A History of Al-Kanemi Dynasty of Borno. Oxford: Clarendon Press; 1973. 145 p.

15. Last M, Al Hajj MA. "Attempt at defining a Muslim in the 19th Century Hausaland and Borno". Journal of Historical Society of Nigeria. 1971;26(3):308-324.

16. Humphrey J Fisher. The Fulani 'Jihād' Tazȳ̄n al Waraqāt. In: Abdullahi Fodiyo, Tazyin al Waraqat, Hikett M, editors. Ibadan University Press; 1963;7(2):344-347.

17. Abdullah, 87.

18. Bello. Infaqul Maisur. 87.

19. Kyari Tijjan. A Political Economy Perspective in Borno Museum Society Newsletter. Newyork: Newsletter; 1982. 21-28 p.

20. Cohen R, Brenner L. Bornu in the Nineteenth Century. In: Ade Ajayi JFA, Crowder M, editors. People and Empires in African History: Essays in honor of Michael Crowder. London: Longman; 199. 254 p.

21. Abba Y. The Jihad in Hausaland as a Revolution. In; Usman YB, editor. Studies in the History of the Sokoto Caliphate”. Nigeria: Third Press International; 1979. $22 \mathrm{p}$.

22. El-Masri FH, Bayan Wujub al-Hijrah ala al-Ibad. UK: University of Ibadan; 1963.358 p.

23. Kyari T. "Political and Constitutional Change in Borno under Shehu Muhammad al-Amin al-Kanemi; The Case of the Majilis". In: Usman B, Alkali N, editors. Studies in the History of Pre-Colonial Borno. Zaria: NNPC; 1983. $236 \mathrm{p}$.

24. Kyari T. "Political and Administrative Development in Pre-colonial Borno". Information, Society and justice. 1980;2(1):137-162.

25. Yamusa S. The Political Ideas of the Jihad Leaders: Being translation, edition and analysis of a Usul al-Siyasat of Muhammad Bello. pp. 90103.

26. Gwandu AA. "The Nature and Character of Shaykh Abd Allah B. Foduye". In: Gwandu AA, et al, editors. The Sokoto Caliphate: A Legacy of Scholarship and Good Governance. Sokoto: Usmanu Danfodiyo University; 2005. 16-17 p.

27. Kyari Tijjani. Issues in the Shari'ah Debate-Learning from al-Kanemi (a Political Economy Perspective) in Borno Museum Society Newsletter. Nigeria: Newsletter; 1989. 21-28 p.

28. Bello, Infaqul Maisur, 100.

29. Bello, Infaqul Maisur, 100. 
30. Bello, Infaqul Maisur, 100

31. Bello, Inafqul Miasur, 101

32. Bello Infaq al-Maisur. 103.

33. Bello Infaq al-Maisur, 107.

34. Bello Infaq al-Maisur. 108.
35. Bello Infaq al-Maisur 109 .

36. Bello Infaq al-Maisur. 113.

37. Bello Infaq al-Maisur 115 .

38. Bello Infaq al-Maisur. 119

39. Brenner, The Shehu's of Kukawa. 40-41. 